\title{
同位体希釈質量分析法による耐熱合金中の 微量ホウ素の定量
}

\author{
Determination of Traces of Boron in Heat-Resisting Alloy \\ Standards by Isotope Dilution Mass Spectrometry \\ 田村修三 \\ SHUZO TAMURA
}

(1973年12月15日受理)

\begin{abstract}
Traces (0.6 130ppm) of boron in heat-resisting alloy standards of J AERI (Japan Atomic Energy Research Institute) and of NBS (National Bureau of Standards, U. S. ) were determined by isotope dilution mass spectrometry which involved addition of $95^{\prime} \%$ enriched boron-10 as the spike and isolation of boron from acid solution of samples by methyl borate distillation. The tantalum ribbon single filament technique was used for isotopic analysis of boron.

Except for one JAERI standard, the results obtained by isotope dilution gave a relative standard deviation of less than $3 \%$. Determination of boron in boron-added water samples, fly ash standard NBS 1633 and geochemical rock standards JG-1 and JB-1 was also carried out for comparison.
\end{abstract}

\section{1.はじめに}

高温ガス炉用材料のニッケル基および鉄基耐熱合金 について, 現在, 本研究所核燃料・炉材料等分析委員 会で 9 種類の標準試料 JAERI R $1 \sim R 9$ を中心に共 同分析がすすめられている。筆者はこれらの標準試料 と National Bureau of Standards, USAのワスパロ イ系合金標準試料 NBS SRM 349 に含まれる0.6 $130 \mathrm{ppm}$ の微量ホウ素を同位体希釈質量分析法で定量 することを検討した。

この方法によるホウ素の定量についてはいくつかの 報告がある。 JAERI U $1 \quad\left(\mathrm{U}_{3} \mathrm{O}_{8}\right)$ に含まれる $0.3 \sim 2.4 \mathrm{ppm}$ のホ ウ素を定量したが）当時の質量分析計では同位体比測 定誤差が約 $1 \%$ 以上った。その後，イオン化フィラ メント電源に高安定度 $( \pm 0.01 \%)$ の回路を使用し, またフィラメント電流の制御や試料量などの測定条件 を検討して，例えばウランについて ${ }^{235} \mathrm{U} /{ }^{238} \mathrm{U}$ 同位
体比を $\pm 0.1 \%$ 程度の相対誤差で測定できる状況にな つた。)

NBS における標準試料表示值の決定が同位体希釈 質量分析によって行なわれたのは, ${ }^{7}$ 高純度標準物質 および “Clean Lab.”の整備とともに，最近の同位 体比測定技術の全般的な進少によるところが大きい。

本検討では, 試薬精製やブランク值の改善など解決 すべき問題があるが、微量ホウ素の分析精度として一 応良好な結果が得られたので報告する。

\section{2. 実験}

\section{1 試薬および装置}

ホウ素スパィク溶液：NBS SRM 952 (ホウ酸, 化 学純度 $\left.99.97 \pm 0.02 \%,{ }^{10} \mathrm{~B} /{ }^{1} \mathrm{~B}=18.80 \pm 0.02\right)^{9)}$ 再蒸留水に溶かし, $36.50 \mu \mathrm{g} \mathrm{B} / \mathrm{g}$ の溶液をつくり,天 然同位体比のホウ素標準溶液による濃度較正をせずに 用いた。6カ月以内に調製したスパイク溶液を用い, ポリエチレンびんに保存した。

*日本原子力研究所東海研究所分析七ンター (茨城県那珂郡東海村)

Japan Atomic Energy Research Institute (Tokai-mura, Naka-gun, Ibaraki-ken, Japan) 
ホウ素標準溶液（同位体比測定用）：NBS SRM

951 (ホウ酸, 化学純度 $100.00 \pm 0.01 \%,{ }^{10} \mathrm{~B} /{ }^{11} \mathrm{~B}=$ $0.2473 \pm 0.0002)^{9)}$ を再蒸留水に溶かし, $1.00_{0} \mathrm{mg}$ $/ \mathrm{g}$ の溶液をつくり, 同位体比測定の標準に用いた。

再蒸留水: 銅製蒸留器による一次蒸留水をシリカ製 蒸留器で再蒸留し，2週問以内に用いた。

硫酸 $(1+1) ：$ フ化水素酸を添加した特級試薬 硫酸を白金皿にとり，硫酸白煙の出るまで加熱し，放 冷後ふたたび上記の操作を行ない処理した硫酸を再蒸 留水で希䣋して調製し、ポリプロピレンびんに保存し た。

塩酸および硝酸：特級試薬を精製せずにホウ菜ブラ ンク值を求めてから使用した。

再蒸留メタノール：試薬 1 級メタノールに試薬特級 水酸化ナトリウム（錠戍状）を加え，シリ力製蒸留裴 思で 2 回蒸留し、ポリプロピレンびんに保存して用い た。

0.1\%炭酸ナトリウム溶液：Merck 社 “Suprapur” 炭酸ナトリウムを再蒸留水に溶かして用いた。

$1 \%$ グリセリン溶液：試薬特級グリセリンを再蘶留 水に溶かして川いた。

シリカ蒸留装置 : 約 $100 \mathrm{~m} l$ のフラスコ部分, $50 \mathrm{~m} l$ 漏斗付きすり合せ栓を储えた全シリカ製蒸留裴喕を川

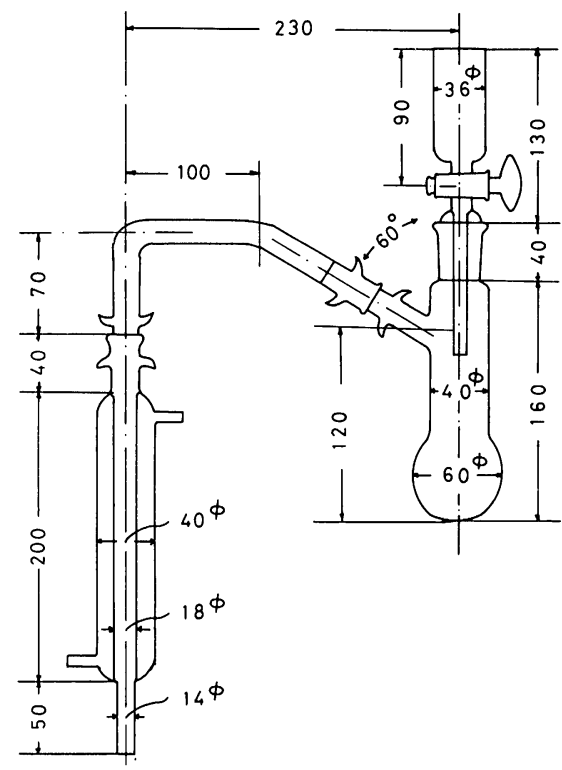

Fig. 1. Methyl borate distillation apparatus (silica). Scales are shown in $\mathrm{mm}$.
いた（Fig. 1)。試料の酸溶解にもこのフラスコに漏 斗付きすり合せ栓をつけて使用した。

その他：白金器具はフッ化水素酸 $(1+99)$, 塩酸 $(1+9)$ に浸漬し, 再蒸留水でよく洗ってから乾燥 して, 使用直前にブンゼンバーナーで赤熱してから使 用した。ミクロピペット用チップ、その他のポリエチ レン製容器もエタノール浸渍後、フッ化水索酸 $(1+$ 99），塩酸（1+9) などでよく洗浄してから使用し た。

質量分析計：イオン半径 $305 \mathrm{~mm}$, 偏向角 $60^{\circ}$ のCEC 21-702B型啠量分析計を用いた。加速電圧 $7 \mathrm{kV}$ ，モー ター駆動制御および手動による磁場走査で, ファラデ 一カップ・振動容照型電位計・ペン記録部の娭出系に より測定した。

\section{2 定量操作}

\section{2 .1 スパイク添加および試料溶解}

$100 \mathrm{ml}$ シリカ製ビーカーに試料数グラムをとり, アセトン, 再蒸留メタノールでそれぞれ 2 回洗浄して $80^{\circ} \mathrm{C}$ で乾燥後, シリカゲルを入れたデシケーター中で 放冷保存した。この洗浄ずみ試料の $0.2 \sim 2 \mathrm{~g}$ （1～ $30 \mu \mathrm{gB})$ をはかりとり, あらかじめ $30 \mathrm{~m} l$ 白金ルッボ に秝取したホウ素スパイク溶液 (理想混合比 $\mathrm{C}_{i k}=\left(\mathrm{A}_{i k}\right.$ $\left.\times \mathrm{B}_{i k}\right)^{1 / 2} \simeq 2$ ) とともに $100 \mathrm{ml}$ シリカ製蒸留フラス コに加えた。器壁に付着した試料片およびスパイク溶 液を再蒸留水 $40 \sim 50 \mathrm{~m} l$ でフラスコ底部に洗いおとし， 塩酸 $3 \mathrm{~m} l$, 硫酸 $(1+1) 20 \mathrm{~m} l$ を加えた。漏斗付き すり合せ栓をフラスコにつけて，500W赤外線ランプ 下 $20 \mathrm{~cm}$ (近傍温度 $150^{\circ} \mathrm{C}$ ) で加熱し, 試料を溶解した (所要時間 : 数時間〜百数十時間)。ほとんど溶解し たところで硝酸 $3 \mathrm{~m} l$ 加え, さらに加熱して完全に 溶解させた。試料溶解後, 液量が約 $15 \mathrm{~m} l$ になるまで 加熱蒸発させ, 冷却後, 再蒸留メタノール $50 \mathrm{ml}$ をフ ラスコに加えた。

2.2 .2 ホウ酸メチル蒸留および啠量分析用試料の 調製

メタノールを加えた蒸留フラスコに側管・冷却管を 手早くとりつけ，すり合せ部分をスプリングで締めて から, $90 \pm 1{ }^{\circ} \mathrm{C}$ に保持した湯浴中に蒸留フラスコを浸 してホウ酸メチル蒸留を行なった。留出液はあらかじ め $1 \%$ グリセリン溶液 $0.5 \mathrm{~m} l, 0.1 \%$ 炭酸ナトリウム 溶液 $0.1 \mathrm{~m} l$ および再蒸留水 $20 \mathrm{~m} l$ を入れた $100 \mathrm{~m} l$ 白金血に受けた。メタノール留出の終了後, 白金血に 
再蒸留水 $30 \mathrm{~m} l$ を加えて蒸発乾固した。残分を再蒸留 水 $1 \sim 2$ 滴に溶かし, 質量分析用試料とした。

\section{2 .3 木ウ素同位体比の測定（質量分析）} あらかじめ, $1 \times 10^{-6}$ Torr以下の真空度に保ったフィ ラメント焼出し装置で $4.5 \mathrm{~A}$ で約 2 時間空焼きした夕 ンタルリボンのフィラメント $(0.03 \times 0.75 \times 14 \mathrm{~mm})$ に, $5 \sim 15 \mu \mathrm{g} \mathrm{B}$ を含む試料液をマイクロピペット $(5 \mu l)$ で塗布し, 空気中で $1.8 \mathrm{~A}$ の電流を通じ, 水分が蒸発 し，さらにタール状になるまで加熱してから，質量分 析計イオン源に挿入した。

排気してイオン源真空度が $1 \times 10^{-6}$ Torr 以下になっ たのち、フィラメントの加熱を始めた。フィラメント 電流 $1.0 \mathrm{~A}$ までは, イオン源真空度が $5 \times 10^{-6}$ Torr を越えない範囲で，比較的短時間に電流を上げた。 $1.0 \sim 1.8 \mathrm{~A}$ までは 3 分ごと $0.1 \mathrm{~A}$ の㓶合で電流を上げ ていき，その時娭出される ${ }^{2}{ }^{3} \mathrm{Na}+$ イオン強度が最大に なるようにイオン源レンズ電位を調整した。

約 $1.8 \mathrm{~A}$ で $\mathrm{Na}_{2} \mathrm{BO}_{2}^{+}$イオンを娭出 $\left(\sim 3 \times 10^{-15} \mathrm{~A}\right)$ し たのちは， 6 分ごと $0.1 \mathrm{~A}$ 以下の割合でイオン強度の 変動をみながら電流增加を行なった。そして, $\mathrm{Na}_{2} \mathrm{BO}_{2}{ }^{+}$ イオン電流が $3 \times 10^{-13} \mathrm{~A}$ 程度になったのちは, 安定 なイオン電流が得られるようにフィラメント電流を微 調節（ $\pm 0.05 \mathrm{~A}$ 以下）して，2〜3点のイオン電流值 でデータをとった。すなわち，大きい方のピークの読 みが $30 \mathrm{mV}, 100 \mathrm{mV}, 300 \mathrm{mV}$ (初段抵抗 $1 \times 10^{11} \Omega$ ) の各レンジにあるとき，同位体比 ${ }^{23} \mathrm{Na}_{2}{ }^{1}{ }^{0} \mathrm{BO}_{2}^{+} /{ }^{2}{ }^{3} \mathrm{Na}_{2}$ ${ }^{1} \mathrm{BO}_{2}^{+}(88 / 89)$ をそれぞれのレンジで 8 10 組 測定した。マススペクトルは磁場電流制御用抵抗器 の調節により $, m / e=88,89$ のピークの中央部を交互 に30秒ずつ記録させる方式 (discrete step) で走查 した。

各レンジでの同位体比平均值が相対標準偏差0.2 $0.5 \%$ 範囲で一致ししたときの，低いフィラメント 電流値で測定された同位体比 $R(88 / 89)$ を採用した。 そして ${ }^{17} \mathrm{O}$ による $m / e 89$ への寄与 $\left({ }^{23} \mathrm{Na}_{2}{ }^{10} \mathrm{~B}{ }^{16} \mathrm{O}\right.$ $\left.{ }^{17} \mathrm{O}^{+}\right)$を ${ }^{17} \mathrm{O} /{ }^{16} \mathrm{O}=0.000395(\mathrm{NBS} \text { 值 })^{9)}$ としてホウ 素同位体比 $R\left({ }^{10} \mathrm{~B} /{ }^{11} \mathrm{~B}\right)=R(88 / 89) /[1-0.00079$ $\times R(88 / 89)$ )を求め，(1)式により同位体希 釈法の計 算を行なった。

$$
x(\mathrm{~g})=y(g) \cdot \frac{b_{k}}{a_{k}} \cdot \frac{M_{x}}{M_{y}} \cdot \frac{B_{i k}-C_{i k}}{C_{i k}-A_{i k}}
$$

ここで, $x(\mathrm{~g}), y(\mathrm{~g})$ はそれぞれ試料およびスパイ ク中のホウ素重量 $(\mathrm{g}), \mathrm{a}_{k}, b_{k}$ は試料，スパイク中の ホウ素同位体 ${ }^{11} \mathrm{~B}$ の原子分率, $M_{x}, M_{y}$ は試料, スパイ ク中のホウ素の原子量, そして $A_{i k}, B_{i k}, C_{i k}$ は試料, スパイク, 混合物中のホウ素同位体比 $R\left({ }^{10} \mathrm{~B} /{ }^{11} \mathrm{~B}\right)$ で ある。

なお，試薬・定量操作によるブランク値を求めてホ ウ素検出值 $x(\mathrm{~g})$ から差引き, 示ウ素含有量 $(\mathrm{ppmB})$ を算出した。

\section{3. 検討および考察}

\section{1 ホウ酸メチル蒸留および質量分析用試料の調 製}

ホウ素低含有の試料 JAERI R $6(0.6 \mathrm{ppmB}) 0.2 \mathrm{~g}$ を用い, 約 2 及び $10 \mu \mathrm{g}$ のホウ素を添加し，酸による 試料溶解およびホウ酸メチル蒸留の操作を通じてのホ ウ素の回収率を同位体希釈法で求めた。Table 1 に示 すように，ホウ素が定量的に回収されることが確めら れた。

Table 1. Recovery of boron (methyl borate distillation).

\begin{tabular}{lcc}
\hline $\begin{array}{l}\text { Boron } \\
\text { added }(\mu \mathrm{g}) *\end{array}$ & $\begin{array}{l}\text { Boron } \\
\text { found }(\mu \mathrm{g}) * *\end{array}$ & Recovery(\%) \\
\hline 2.14 & 2.18 & 102 \\
10.70 & 10.71 & 100 \\
\hline
\end{tabular}

$* 0.2 \mathrm{~g}$ of the JAERI R6 sample $(0.6 \mathrm{ppm} \mathrm{B})$ was used $* *$ Determined by isotope dilution. Average boron blank value, $0.23 \pm 0.05 \mu \mathrm{gB}$, was subtracted.

留出受液中にアルカリが過剩にあるとNa ${ }_{2} \mathrm{BO}_{2}^{+}$イオン が検出されるフィラメント温度が高くなり，かつイオ ン電流が不安定になって同位体比測定を困難にする。 したがってアルカリ量をなるべく少なくするために， すでにPérié ら ${ }^{2)}$ が用いているグリセリン添加を行 なった。 。また，添加するアルカリ塩としては水酸化ナ トリウムより炭酸ナトリウムを用いたほうが安定なイ オン電流と時間的変動の少ない同位体比が得られるこ とが知られている。 P) Périé らは鉄鋼中ホウ素 (2.6〜

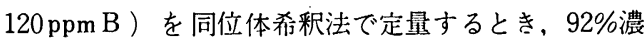
縮 ${ }^{10} \mathrm{~B}$ 約 $10 \mu \mathrm{g}$ を試料 1 $2 \mathrm{~g}$ に添加し， $85 \% \mathrm{H}_{3} \mathrm{PO}_{4}$ $10 \mathrm{~m} l$ に溶解後, メタノール $50 \mathrm{~m} l$ を用いて蒸留分離を 
行ない, N/100水酸化ナトリウム（1％グリセリン） 溶液 $5 \mathrm{~m} l$ を加えた蒸留水 ( 3 回蒸留) $25 \mathrm{~m} l$ を留出 受液としている。我々はPériéらの述べている量の約 10分の 1 のアルカリおよびグリセリンの添加でもホウ 装が留出受液の蒸発乾固時に逸出しないことを確め

(Table 2), 試料十スパイク中のホウ素合量15 60 $\mu \mathrm{g}$ $\mathrm{B}$ に対し， $\mathrm{Na} \simeq 50 \mu \mathrm{g}$, グリセリン $=5 \mathrm{mg}$ の割合に なるようにした。

\section{2 ホウ素同位体比の測定（質量分析）}

表面電離啠量分析によるホウ素同位体比測定し関し ては多くの研究があり，㩆近ではとくにCatanzaro ら. ${ }^{9)}$ de Bièvre $~^{10)}$ の報告がくわしい。前者はタンタ ルシングルフィラメント法（試料晴〜 $10 \mu \mathrm{g} \mathrm{B}$ )を、後
者はレニウムトリプルフィラメント法（試料践 $2 \times$ $100 \mu \mathrm{g} \mathrm{B}$ )を用い，ホウ素同位体標準物質 (ホウ酸) の同位体比表示值の決定を相対誤差 $\pm 0.1 \%$ 以下の精 度および正確度で行なっている。

我々はトリプルフィラメント法についても検討した が、フィラメント焼出しなどの手間がより少ないこと フイラメント電流が制御しやすいこと、試料のイオン 源への捰大から測定終了までの所要時間の短かいこと などの点から、シングルフィラメント法を採用した。 $5 \sim 15 \mu \mathrm{g} \mathrm{B}, 10 \sim 30 \mu \mathrm{g} \mathrm{Na}(\mathrm{Na} / \mathrm{B}$ (原子比) $=0.5 \sim 2$ ), および0.5 1 mg グリセリンをタンタルリボンのフィラ メント $(0.03 \times 0.75 \times 14 \mathrm{~mm})$ に塗付し，Fig. 2 に示す 一定の割合でフィラメント電流を增加し， $2.0 \pm 0.2 \mathrm{~A}$

Table 2. Loss of boron during evaporation of distillate.

\begin{tabular}{ccc}
\hline $\begin{array}{l}\text { Reagents added } \\
\text { to distillate* }\end{array}$ & $\begin{array}{l}\text { Boron } \\
\text { added }(\mu \mathrm{g})\end{array}$ & $\begin{array}{l}\text { Boron found after } \\
\text { evaporation }(\mu \mathrm{g})^{* *}\end{array}$ \\
\hline$\left(\mathrm{H}_{2} \mathrm{SO}_{4}(1+1)\right.$ & 2.14 & 1.55 \\
$0.1 \mathrm{~m} l)$ & 10.7 & 3.51 \\
$\left(\begin{array}{ccc}0.1 \% \mathrm{Na}_{2} \mathrm{CO}_{3} & 0.1 \mathrm{~m} l \\
1 \% \text { glycerol } & 0.5 \mathrm{~m} l\end{array}\right)$ & $\begin{array}{c}2.35 \\
10.7\end{array}$ & 2.62 \\
\hline
\end{tabular}

* $50 \mathrm{~m}$ ! of redistilled water was added.

** Determined dy isotope dilution. Boron blank included.

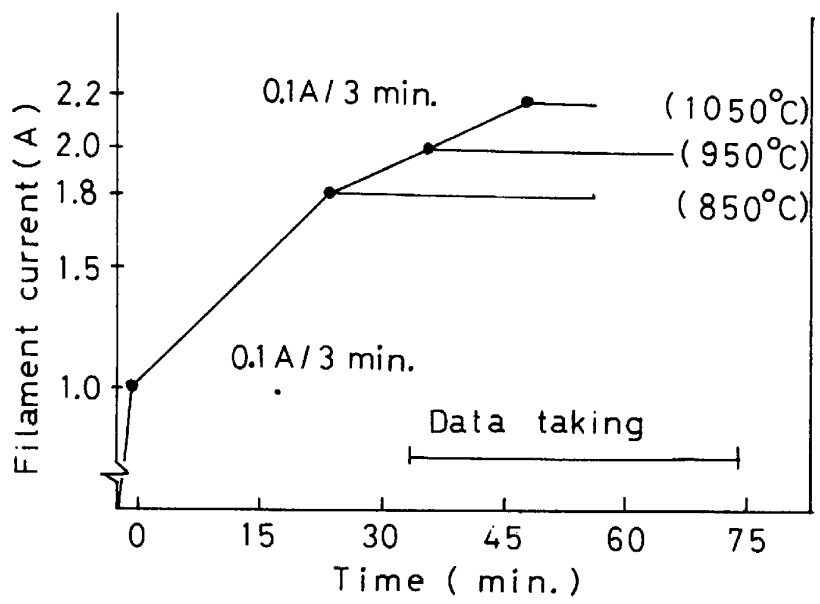

Fig. 2. Analytical pattern for mass spectrometry of boron. 
同位体希釈質量分析法による耐熱合金中の微量ホウ素の定量

Table 3. Observed isotopic ratios of boron in NBS SRM 951.

\begin{tabular}{c|ccc}
\hline & $\left({ }^{0} \mathrm{~B} /{ }^{11} \mathrm{~B}\right)_{c}^{*}$, Av. and st. dev. (No. of measurements) \\
\hline Anal. No. & $10 \mathrm{mV} / 30 \mathrm{mV}$ & $30 \mathrm{mV} / 100 \mathrm{mV}$ & $100 \mathrm{mV} / 300 \mathrm{mV}$ \\
\hline 1794 & $0.2472 \pm 0.00078(8)$ & $0.2477 \pm 0.00037(12)$ & $0.2473 \pm 0.00051(11)$ \\
1843 & $0.2473 \pm 0.00031(8)$ & $0.2471 \pm 0.00031(8)$ & $0.2471 \pm 0.00053(10)$ \\
1855 & $0.2479 \pm 0.00057(10)$ & $0.2474 \pm 0.00024(10)$ & $-* *$ \\
\hline $\begin{array}{l}\text { Av. of av. and } \\
\text { st. dev. }\end{array}$ & $0.24747 \pm 0.00038(3)$ & $0.24740 \pm 0.00030(3)$ & $0.2472_{0} \pm 0.0001(2)$ \\
\hline $\begin{array}{l}\text { Grand av. and } \\
\text { st. dev. }\end{array}$ & & $0.2473_{8} \pm 0.00029(8)$ & \\
\hline
\end{tabular}

* Corrected for ${ }^{17} \mathrm{O} /{ }^{16} \mathrm{O}=0.000395$.

** Not measured.

Table 4. Observed isotopic ratios of boron in NBS SRM 952.

\begin{tabular}{c|ccc}
\hline & $\left({ }^{0} \mathrm{~B} /{ }^{11} \mathrm{~B}\right)_{c}^{*}$, Av. and st. dev. (No. of measuerements) \\
\hline Anal. No. & $100 \mathrm{mV} / 10 \mathrm{mV}$ & $300 \mathrm{mV} / 10 \mathrm{mV}$ & $300 \mathrm{mV} / 30 \mathrm{mV}$ \\
\hline 1786 & $18.84 \pm 0.074(8)$ & $18.75 \pm 0.032(12)$ & $18.78 \pm 0.059(12)$ \\
1788 & $18.73 \pm 0.047(10)$ & $18.81 \pm 0.055(8)$ & $18.74 \pm 0.033(10)$ \\
1789 & $18.83 \pm 0.053(10)$ & & $18.74 \pm 0.044(12)$ \\
1802 & $18.74 \pm 0.068(10)$ & $18 *$ & $18.81 \pm 0.043(12)$ \\
1811 & $18.87 \pm 0.041(22)$ & $18.85 \pm 0.054(9)$ & \\
1812 & $18.82 \pm 0.017(10)$ & $18.82 \pm 0.079(8)$ & $18.84 \pm 0.026(16)$ \\
1815 & $18.85 \pm 0.020(8)$ & $18.84 \pm 0.036(13)$ & $18.78{ }_{2} \pm 0.044(5)$ \\
\hline $\begin{array}{l}\text { Av. of av. and } \\
\text { st. dev. }\end{array}$ & $18.81_{1} \pm 0.055(7)$ & $18.81_{4} \pm 0.039(5)$ & \\
\hline Grand av. and & & $18.80_{4} \pm 0.047(17)$ & \\
st. dev. & & & \\
\hline
\end{tabular}

* Corrected for ${ }^{17} \mathrm{O} /{ }^{1}{ }^{6} \mathrm{O}=0.000395$

** Not measured.

$\left(950 \pm 100^{\circ} \mathrm{C}\right)$ で測定したホウ素同位体標準試料 NBS 951 および952についての結果をそれぞれ Table 3 お よびTable 4 に示した。

相対標準偏差は NBS 值の約 $2 \sim 3$ 倍大きいが, 平 均値 $\left({ }^{\circ} \mathrm{B} /{ }^{11} \mathrm{~B}\right)$ としては表示値とバイアスの小さい 良い一致をそれぞれ示している。また，本検討による 同位体比測定値が時間経過およびイオン強度の增加の もとでもあまり顕著に変動しないことをFig. 3に例示
した。ただし，アルカリ量が多すぎたり，不純物の多 い場合には，同位体比が時閪経過およびイオン強度の 增隇とともに変化することが 2,3 の例で認められた ことがあったので, 2.2 .3 に述べたように各レンジで 一応同位体比を測定し，巽常な変動がないことを確か めることにした。

一般にホウ素の天然同位体比は, 鉱物起源などによ $\eta^{10} \mathrm{~B} /{ }^{1} \mathrm{~B}=0.235 \sim 0.250$ の篹囲（日本産鉱物）で変 


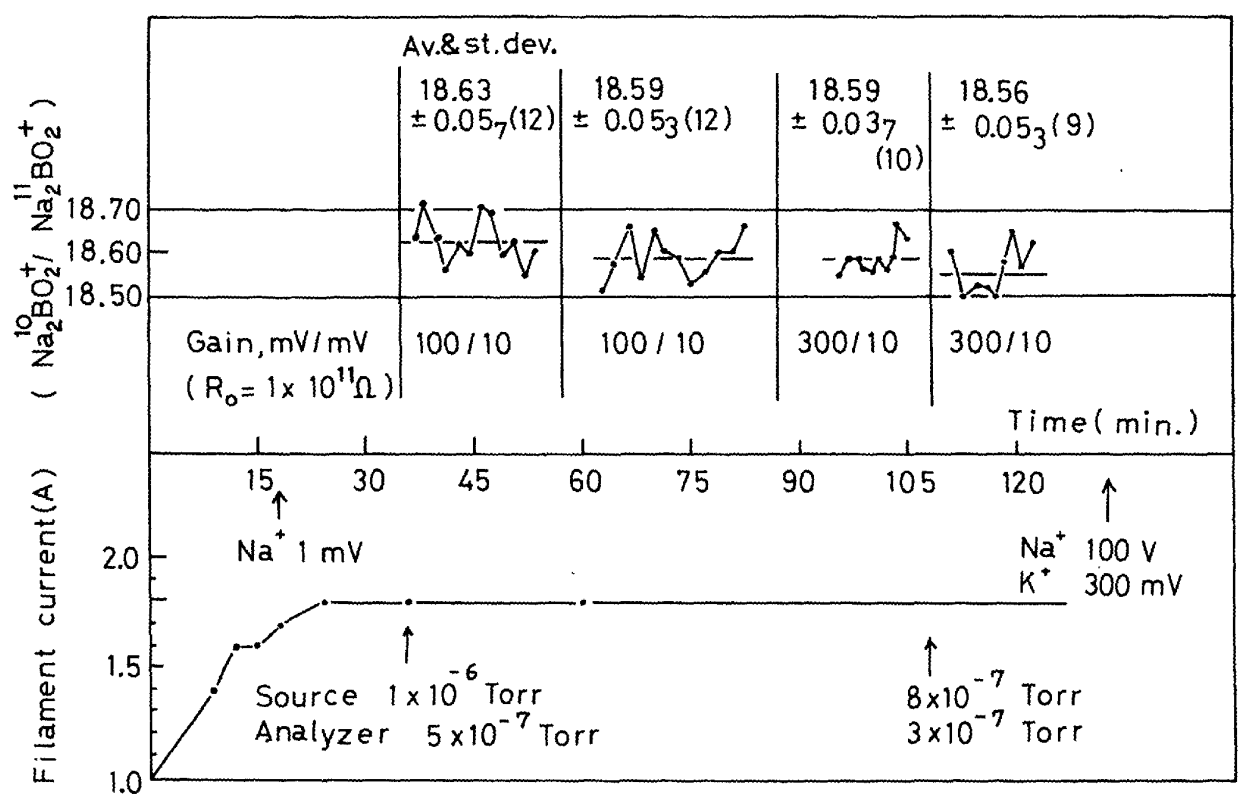

Fig. 3. Variation of observed isotopic ratios $\left(\mathrm{Na}_{2}^{10} \mathrm{BO}_{2} / \mathrm{Na}_{2}{ }^{1} \mathrm{BO}_{2}\right)$ for NBS SRM 952 with time and ion curent intensity.

Table 5. Observed isotopic ratios of boron for heat-resisting alloy standerds.

\begin{tabular}{|c|c|}
\hline Description & $\begin{array}{l}\qquad\left({ }^{0 \mathrm{~B}} /{ }^{11} \mathrm{~B}\right)_{c}^{*} \\
\text { Av. and st. dev. (No. of measurents) }\end{array}$ \\
\hline \multirow[t]{9}{*}{ JAERI } & $0.2488 \pm 0.00043(10)$ \\
\hline & $0.2479 \pm 0.00050(8)$ \\
\hline & $\ldots *$ \\
\hline & $0.2481 \pm 0.00054(8)$ \\
\hline & $0.2499 \pm 0.00121(8)$ \\
\hline & $\underbrace{* *}$ \\
\hline & $0.2471 \pm 0.00075(8)$ \\
\hline & $0.2454 \pm 0.00134(8)$ \\
\hline & $0.2463 \pm 0.00104(9)$ \\
\hline NBS 349 & ]$^{* *}$ \\
\hline $\begin{array}{l}\text { Av. of av. } \\
\text { and st. dev }\end{array}$ & $0.2476 \pm 0.00152(\mathrm{~N}=7)$ \\
\hline
\end{tabular}

* Corrected for ${ }^{17} \mathrm{O} /{ }^{16} \mathrm{O}=0.000395$. ** Not measured.

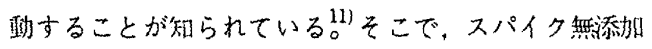
で $0.3 \sim 1 \mathrm{~g}(10 \sim 35 \mu \mathrm{g} \mathrm{B})$ の耐熱合金をとり, 2.2.1〜2.2.3の操作にしたがい，ホウ素同位体比を測
定した (Table 5)。JAERI R6 はホウ素が低含有估 であり、またNBS 349 は試料が不足していたので測 定していないが，同位体希彩法の $A_{i k}$ 值としてはこれ 5の平均继 ${ }^{\circ} \mathrm{B} /{ }^{\circ} \mathrm{B}=0.2476 \pm 0.0015$ を用いた。 $A_{i k}$ が0.235 0.2500籍用で変動すると仮定すると、平均

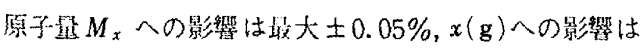
R 6の場合で谈大 $\pm 0.088 \%$, NBS 3490場合には早大 $0.44 \%$ と計算された。(Table 6の数值を优朋)。

\section{4. 実験結果}

同位体希釈法の部算に用いたデー夕をTable 6 に, また同位体养釈定焉值（ppm B）上本研究所の随四ら によるクルクミン光废法定些値 ${ }^{12)}$ を併せて Table7に それぞれ示した。

なお，JAERI R1〜R3 はインコネルX750系, R 4 はインコネル 713系, R 5 およびR 6 はインコネル 600 系， R 7 およびR 8 はインコロイ 800系， R 9は 八ステロイ系, NBS 349はワスパロ係合金に属する。 JAERI R 1 ～R 9 はディスク状試料であり，化学分 析のために切削の過程が必要であるが，NBS 349 は $0.5 \times 0.4 \times(2 \sim 3) \mathrm{mm}$ ぐらいの細かいチップ状の試料 である。 


\section{同位体希釈質量分析法による耐熱合金中の微晊ホウ素の定量}

Table. 6. Data for isotope dilution calculations.

\begin{tabular}{|c|c|c|c|c|c|c|}
\hline Sample & \multirow{2}{*}{$\frac{\text { Run No. }}{1947}$} & \multirow{2}{*}{$\begin{array}{l}\text { Sample. } \\
\text { taken }(\mathrm{g}) \\
-\end{array}$} & \multirow{2}{*}{$\begin{array}{l}\begin{array}{l}\text { Spike } \\
\text { added }(\mu \mathrm{gB})\end{array} \\
14.64\end{array}$} & \multirow{2}{*}{$\begin{array}{c}C_{i k} \\
\text { Av. and st. dev. (n) } \\
14.7 .0 \pm 0.022(10)\end{array}$} & \multicolumn{2}{|c|}{$\begin{array}{l}\text { Boron } \\
\text { found }(\mu \mathrm{g})^{* *}\end{array}$} \\
\hline \multirow{4}{*}{ Blank } & & & & & 0.28 & \multirow{4}{*}{$\begin{array}{l}\text { (Av and st. dev.) } \\
0.23 \pm 0.05(4)\end{array}$} \\
\hline & 1960 & - & 13.98 & $15.89 \pm 0.045(6)$ & 0.16 & \\
\hline & 2009 & - & 13.41 & $14.77 \pm 0.090(9)$ & 0.24 & \\
\hline & 2105 & - & 14.91 & $15.50 \pm 0.069(14)$ & 0.22 & \\
\hline \multirow{3}{*}{ JAERI } & 2051 & 0.2359 & 22.10 & $1.779 \pm 0.0036(10)$ & \multicolumn{2}{|l|}{16.63} \\
\hline & 2052 & 0.3131 & 43.89 & $2.457 \pm 0.0076(10)$ & \multicolumn{2}{|l|}{21.98} \\
\hline & 2054 & 0.2289 & 44.95 & $3.220 \pm 0.0040(10)$ & \multicolumn{2}{|l|}{15.95} \\
\hline \multirow{3}{*}{ JAERI } & 2040 & 0.2875 & 27.29 & $3.197 \pm 0.0035(8)$ & \multicolumn{2}{|c|}{9.772} \\
\hline & 2042 & 0.3030 & 29.17 & $3.195 \pm 0.0078(8)$ & \multicolumn{2}{|l|}{10.45} \\
\hline & 2044 & 0.3171 & 31.54 & $3.401 \pm 0.0092(8)$ & \multicolumn{2}{|l|}{10.43} \\
\hline \multirow{3}{*}{ JAERI } & 2046 & 0.1806 & 48.92 & $2.509 \pm 0.0012(10)$ & \multicolumn{2}{|l|}{23.86} \\
\hline & 2047 & 0.2377 & 47.09 & $1.990 \pm 0.0052(10)$ & \multicolumn{2}{|l|}{30.75} \\
\hline & 2049 & 0.2785 & 55.06 & $1.991 \pm 0.0039(11)$ & \multicolumn{2}{|l|}{35.93} \\
\hline \multirow{3}{*}{ JAERI } & 1995 & 0.2199 & 31.35 & $1.764 \pm 0.0042(10)$ & \multicolumn{2}{|l|}{23.84} \\
\hline & 1999 & 0.2295 & 31.66 & $1.665 \pm 0.0029(11)$ & \multicolumn{2}{|l|}{25.91} \\
\hline & 2014 & 0.1639 & 31.44 & $2.163 \pm 0.0053(10)$ & \multicolumn{2}{|l|}{18.49} \\
\hline \multirow{3}{*}{ JAERI } & 2084 & 0.4240 & 39.93 & $2.390 \pm 0.0050(8)$ & \multicolumn{2}{|l|}{20.70} \\
\hline & 2083 & 0.3844 & 30.84 & $2.127 \pm 0.0054(11)$ & \multicolumn{2}{|l|}{18.52} \\
\hline & 2085 & 0.4011 & 53.68 & $3.099 \pm 0.0081(8)$ & 20.01 & \\
\hline & 2135 & 2.0353 & 21.92 & $9.104 \pm 0.068(8)$ & 1.62 & \\
\hline JAERI R6 & 2136 & 2.0548 & 20.18 & $8.834 \pm 0.028(8)$ & 1.58 & \\
\hline & 2139 & 2.1992 & 18.84 & $8.312 \pm 0.039(8)$ & 1.65 & \\
\hline & 2090 & 1.0164 & 22.93 & $2.262 \pm 0.0040(10)$ & 12.74 & \\
\hline JAERI R7 & 2089 & 1.0149 & 26.98 & $2.583 \pm 0.0043(8)$ & 12.68 & \\
\hline & 2094 & 1.0216 & 39.42 & $3.453 \pm 0.0068(8)$ & 12.78 & \\
\hline & 2121 & 1.0023 & 25.23 & $3.271 \pm 0.0198(8)$ & 8.77 & \\
\hline JAERI R8 & 2122 & 1.0924 & 23.34 & $3.396 \pm 0.0114(7)$ & 7.73 & \\
\hline & 2123 & 1.0560 & 18.27 & $2.766 \pm 0.0081(8)$ & 7.87 & \\
\hline & 2071 & 1.0993 & 15.38 & $3.954 \pm 0.0084(8)$ & 4.17 & \\
\hline JAERI R9 & 2072 & 1.0151 & 13.69 & $3.925 \pm 0.0080(9)$ & 3.74 & \\
\hline & 2093 & 1.0007 & 13.13 & $3.818 \pm 0.0064(4)$ & 3.72 & \\
\hline$N B S$ & 1963 & 0.1980 & 13.83 & $2.012 \pm 0.0050(8)$ & 8.90 & \\
\hline teds & 1964 & 0.2077 & 14.19 & $1.939 \pm 0.0030(8)$ & 9.57 & \\
\hline
\end{tabular}

* No. of ratios observed in one run. $C_{i k}$ values were corrected for ${ }^{17} \mathrm{O} /{ }^{16} \mathrm{O}=0.000395$.

** $A_{i k}=0.247_{6}$ and $B_{i k}=18.80$ taken from Table 5 and Table 4 , respectively. 
田村

Table 7. Determination of boron in heat-resisting alloy standards by isotope dilution mass spectrometry (ppm B).

\begin{tabular}{|c|c|c|c|c|}
\hline Sample & \multicolumn{2}{|c|}{ This work } & \multicolumn{2}{|c|}{$\begin{array}{l}\text { Distillation- } \\
\text { curcumin method }\end{array}$} \\
\hline \multirow{3}{*}{ JAERI } & 69.52 . & Av. and st.der & 75 & Av. \\
\hline & $69.4_{7}$ & $69.2_{2} \pm 0.4$ & 66 & 68 \\
\hline & $68.6_{8}$ & & 64 & \\
\hline \multirow{3}{*}{ JAERI } & $33.1_{8}$ & & 33 & \\
\hline & $33.7_{3}$ & $33.0_{3} \pm 0.7_{9}$ & 32 & 33 \\
\hline & $32.1_{7}$ & & 33 & \\
\hline \multirow{3}{*}{ JAERI } & 130.8 & & 125 & \\
\hline & 128.4 & $129.1+1.4_{7}$ & 109 & 119 \\
\hline & 128.2 & & 122 & \\
\hline \multirow{3}{*}{ JAERI R4 } & 106.9 & & & \\
\hline & 111.9 & $110.0 \pm 2.7_{4}$ & & $112^{\text {d) }}$ \\
\hline & 111.3 & & & \\
\hline \multirow{3}{*}{ JAERI R5 } & $48.2_{8}$ & & 48 & \\
\hline & $47.5_{8}$ & $48.3_{9} \pm 0.8_{7}$ & 49 & 48 \\
\hline & $49.3_{1}$ & & 46 & \\
\hline \multirow{3}{*}{ JAERI R6 } & $0.68_{3}$ & & $<1$ & \\
\hline & 0.66. & $0.66_{5} \pm 0.01_{6}$ & $<1$ & $<1$ \\
\hline & 0.650 & & & \\
\hline \multirow{3}{*}{ JAERI R7 } & 12.31 & & 14 & \\
\hline & 12.27 & $12.2_{9} \pm 0.02_{1}$ & 13 & 14 \\
\hline & $12.2_{8}$ & & & \\
\hline \multirow{3}{*}{ JAERI R8 } & 8.52 & & & \\
\hline & 6.87 & $7.54 \pm 0.87$ & 6.8 & 7.0 \\
\hline & 7.23 & & & \\
\hline \multirow{3}{*}{ JAERI R9 } & 3.58 & & 4 & \\
\hline & 3.47 & $3.52 \pm 0.05_{7}$ & 5 & 4 \\
\hline & 3.50 & & 3 & \\
\hline \multirow{6}{*}{ NBS 349} & $43.8_{4}$ & $14+t 05+(R)^{c}$ & 42 & \multirow{6}{*}{42.2} \\
\hline & 44.97 & $+44.40 \pm 0.07(\mathrm{n})$ & 42 & \\
\hline & & & 42 & \\
\hline & & & 44 & \\
\hline & & & 42 & \\
\hline & & & 41 & \\
\hline
\end{tabular}

a) Analyzed by Y. Toita et al. (Ref. 12i.

b) NBS certificate : 46

c) Range.

d) Revised value. 
本法の到達可能な繰り返し分析誤差としては, ホウ 酸添加試料水, フライアッシュ (Fly ash, 微粉状) の標準試料 NBS 1633 (ホウ素表示値未定)，および 地質調査所岩石試料 JG-1 および JB-1 (約 100メッ シュ) ${ }^{13)}$ 中のホウ素の定量值が参考になると考えられ るので、これらについての測定結果をTable 8 に示す。 水試料はグリセリン・アルカリ・スパイク添加後、そ のまま蒸発乾固し、フライアッシュおよび岩石試料 はスパイク添加後, 炭酸ナトリウムと溶融し, 硫酸酸 性でメタノール蒸留して，耐熱合金試料の分析操作と
同様にしてホウ素を同位体希棌法で定量した。これら の試料はいずれも耐熱合金よりも試料溶解が比較的容 易で, かつアルカリ性で行なわれ，ブランク值の再現 性もよい場合の例であり，またそれぞれ均一な液体お よび微粉状の試料であるので, 定量值は約土0.8\%以 内の相対標準偏差で得られた。

耐熱合金試料のなかで, R 1, R 3, R 7, NBS 349 の定量值は約 $\pm 0.2 \sim 1 \%, \mathrm{R} 2, \mathrm{R} 4, \mathrm{R} 5, \mathrm{R}$ 6, R 9 が士 $3 \%$ 以内の相対標準偏差で得られている が, R 8 のは約 $10 \%$ 大きな相対標準偏差を示した。

Table 8. Determination of boron in boron-added water samples, fly ash standard NBS 1633, and rock standards JG-1 and JB- 1 by isotope dilution mass spectrometry.

\begin{tabular}{|c|c|c|c|c|}
\hline \multirow[b]{2}{*}{ Water } & \multirow{2}{*}{$\begin{array}{c}\begin{array}{c}\text { Sample } \\
\text { taken }(\mathrm{g})\end{array} \\
1.0268\end{array}$} & \multirow{2}{*}{$\begin{array}{c}\begin{array}{l}\text { Boron } \\
\text { found }(\mu \mathrm{g})\end{array} \\
17.08\end{array}$} & \multicolumn{2}{|c|}{$\begin{array}{l}\text { Boron } \\
\text { found }(\mathrm{ppm})^{*}\end{array}$} \\
\hline & & & 16.61 & Av. \\
\hline Sample A & 1.0073 & 16.80 & 16.66 & \\
\hline \multirow{2}{*}{ Sample B } & 1.1230 & 37.75 & 33.60 & \multirow{2}{*}{33.48} \\
\hline & 1.0931 & 36.47 & 33.35 & \\
\hline \multirow{2}{*}{ Blank I** } & - & 0.020 & & \\
\hline & - & 0.024 & & \\
\hline \multirow{2}{*}{ NBS 1633} & 0.1308 & 62.93 & 480.0 & \multirow{2}{*}{476.0} \\
\hline & 0.1403 & 66.36 & 471.9 & \\
\hline JG-1 & 0.2219 & 1.547 & 6.31 & \multirow{2}{*}{6.26} \\
\hline (Split-9) & 0.1999 & 1.385 & 6.20 & \\
\hline JB-1 & 0.2146 & $2.80_{2}$ & 12.35 & \multirow{2}{*}{$12.3_{5}$} \\
\hline (Split-7) & 0.2187 & $2.85_{0}$ & 12.35 & \\
\hline \multirow{2}{*}{ Blank II *** } & - & 0.15 & & \\
\hline & - & 0.14 & & \\
\hline
\end{tabular}

* Blank values subtracted.

$* * 0.1 \mathrm{~m} l$ of $0.1 \% \mathrm{Na}_{2} \mathrm{CO}_{3}, 0.5 \mathrm{~m} l$ of $1 \%$ glycerol and $10 \mathrm{~m} l$ of redistilled water were taken in a. $50 \mathrm{~m} l$ platinum dish, and the mixture was evaporated to dryness under an infrared lamp.

*** After fusion with $1.2 \mathrm{~g}$ of $\mathrm{Na}_{2} \mathrm{CO}_{3}, 1.5 \mathrm{ml}$ of $\mathrm{H}_{2} \mathrm{SO}_{4}$ and $10 \mathrm{~m} l$. of redistilled water were added. Boron was separated by distillation with $50 \mathrm{ml}$ of redistilled methanol. Reagents in Blank I were also used. 
このR 8 の $C_{i k}$ の测定值（Table 6) は他の $C_{i k}$ に比 ベて精度が劣り，イオン強度のふらつきが認められた。 この原因は合金の組成などによるものと思われるが, 今後の検討辣题である。

以上，本㭘討では組成が複雑で分析困難な耐熱合金 中の微留ホウ素の定五に同位体希釈法を適用し、ひと つの試料を除き，比較的再現性の良い結果を得ること ができた。同位体希釈法が従来のように高感度の分析 法としてのみならず，高精度の分析法として評価でき るものであり、標準試料表示値の決定に有効な方法で あると考えられる。

本報告を行なうにあたり、本研究所小森卓二博士の ご意见をいただいた。またホウ紊同位体比测定の予储 的検討を行なったときに大内 操, 田村公子両氏のご 協力を得た。さらにフライアッシ工標準試料は東京大 学斎藤信房教授よりいただいた。ここで厭く謝意を表 します。（1973年5月25日 日本错些分析学会第21回 年会にて一部を発泰)

\section{文献}

1) D. C. Newton, J. Sanders, and A.C. Tyrrell, Analyst, 85, 870(1960)

2) M. Périê and M. Chemla, Compt. Rend., 254. 1429 (1962) ; M. Përiê, J. Demay and M. Chemla, J.chim phys., 60, 1231(1964).

$3)$ I. Shatokhin, IAEA Technical Note Ser. No. 62 (STI-DOC-10-62). IAEA Vienna (1968), p. 48.

4 ) I. Marsel and D. Milivojević, Mikrochim. Acta, 1971, 353.

5 ) 田村修三・大内 操・小森卓二, 日化第18年会発表 (1965); JAERI 1112(1966).

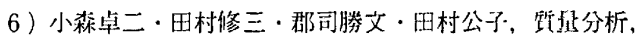
18. $1270(1970)$.

7 ) L. J. Moore and L. A. Machlan, Anal. Chem., 44, 2291 (1972).

$8)$ I. L. Barnes, E. L. Garner, J. W. Graml ich, L. J. Moore, T.J.Murphy, L. A. Machlan, W. R. SThields, M. Tatsumoto, and R. J. Knight, Anal.' Chem., 45. 880(1973).

$9)$ E. J. Catanzaro, C. E. Champion, E. L. Garner, G. Marinenko, K. M. Sappenfield, and W. R. Shields, Nat. Bur. Stand. (U. S. ), Spec. Publ. 260-17(1970).

10) P. J. de Bièvre and G. H. Debus, J.Mass Spectrom. Ion Phys., 2. 15(1969).

11）息誠，理化受研究所報告，39，207(1963).

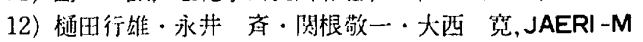
5094(1973).

13) A. Ando, H. Kurasawa, T. Ohmori and E. Takeda, Geochem. J., 5, 151(1971). 